\title{
Genetics, Haloperidol, and the Fos Response in the Basal Ganglia: A Comparison of the C57BL/6J and DBA/2J Inbred Mouse Strains
}

\author{
Nilay Patel, B.S., Barbara Hitzemann, B.S., and Robert Hitzemann, Ph.D.
}

The haloperidol-induced increase of Fos-like immunoreactive (Fos-li) neurons in the basal ganglia was compared in the C57BL/6J (B6) and DBA/2J (D2) inbred mouse strains. The D2 strain is 10-fold more sensitive than the B6 strain to haloperidol-induced catalepsy, a putative animal model of the extrapyramidal symptoms (EPS) seen after the administration of typical neuroleptics. In contrast, the strains are equally sensitive to the haloperidol facilitation of prepulse inhibition of the acoustic startle response, a measure of drug efficacy on the mesolimbic dopamine system. The haloperidol effects on Fos-li neurons were examined over the range of 0.1 to $6.0 \mathrm{mg} / \mathrm{kg}$; the $E D_{50 \mathrm{~s}}$ for haloperidol-induced catalepsy are 0.4 and $3.8 \mathrm{mg} / \mathrm{kg}$ in the D2 and B6 strains, respectively. In neither the core or shell of the nucleus accumbens nor the caudate-putamen (including the dorsolateral aspect) did the D2 strain show a greater Fos response compared to the B6 strain. In fact, in the dorsolateral caudate-putamen, the B6 strain showed a modest but significantly greater Fos response. However, at the output nuclei of the basal ganglia, the entopeduncular nucleus (EP) and the substantia nigra zona reticulata $(\mathrm{SNr})$, the D2 strain consistently showed a greater Fos response. These data suggest that the EP and SNr may be important to understanding the difference in haloperidolinduced catalepsy between the D2 and B6 strains.

[Neuropsychopharmacology 18:480-491, 1998] (C) 1998 American College of Neuropsychopharmacology. Published by Elsevier Science Inc.
KEY WORDS: c-Fos; Basal ganglia; Haloperidol; Genetics; Inbred strains; Catalepsy; Mouse

As detected by both immunocytochemistry and in situ hybridization, $\mathrm{D}_{2}$ dopamine receptor antagonists reliably induced a marked increase of striatal Fos positive neurons (e.g., Miller 1990; Dragunow et al. 1990; Nguyen et al. 1992; Robertson and Fibiger 1992; Deutch and Cam-

From the Departments of Psychiatry (BH, RH), and Neurobiology and Behavior (RH, NP), SUNY at Stony Brook, Stony Brook, NY; and Research and Psychiatry Services (RH), Veterans Administration Medical Center, Northport, NY.

Address correspondence to: Robert Hitzemann, Ph.D., Department of Psychiatry, SUNY at Stony Brook, Stony Brook, NY 117948101.

Received May 23, 1997; revised October 1, 1997; accepted October $14,1997$. eron 1992). Presumably, this increase occurs in a subset of the striatal GABA neurons which are normally tonically inhibited via a $\mathrm{D}_{2}$ receptor mechanism. The Fos response has been shown to have both predictive and construct validity for understanding the mechanisms of antipsychotic drug action. The data supporting this position may be briefly summarized: 1) Typical but not atypical antipsychotics increase the number of Fos positive neurons in the dorsolateral caudate-putamen $(\mathrm{CPu})$ (Dragunow et al. 1990; Nguyen et al. 1992; Deutch and Cameron 1992; Robertson et al. 1994; Ishibashi et al. 1996) although olanzapine, a putative atypical antipsychotic, does show a Fos response similar to haloperidol (Robertson and Fibiger 1996). Since the dorsolateral CPu has an important role in the regulation of movement (Pisa 1988; Carelli and West 1991), these data suggest that the 
Fos response in the area may be predictive of the catalepsy response in rodents and extrapyramidal symptoms (EPS) in humans (Merchant and Dorsa 1993; Robertson et al. 1994; Robertson and Fibiger 1996); 2) Anticholinergic drugs e.g., scopolamine, which block the development of neuroleptic-induced EPS also block the Fos response (e.g., Guo et al. 1992); 3) All clinically effective antipsychotic drugs induce a Fos response in the nucleus accumbens (NAc), this being the only structure to date which consistently predicts therapeutic efficacy (Robertson et al. 1994; Deutch et al. 1996); and 4) Although most of the Fos data has been obtained in rodents, the Fos response in nonhuman primates appears similar (Deutch et al. 1996).

To our knowledge the Fos strategy has not been applied to investigate the genetic variability in neuroleptic response. Among both inbred strains of mice and rats, there are marked differences in sensitivity for haloperidol-induced catalepsy (Kinon and Kane 1989; Kanes et al. 1993). For example, among 40 standard and recombinant inbred mouse strains, the $\mathrm{ED}_{50}$ for haloperidolinduced catalepsy varies more than 30 fold (Hitzemann et al. 1995) and these differences do not appear to be associated with differences in drug uptake or metabolism (Kanes et al. 1993). Correlated traits to the catalepsy response include $\mathrm{D}_{2}$ receptor density, the number of midbrain dopamine neurons, and the number of striatal cholinergic neurons (Qian et al. 1992, 1993; Kanes et al. 1993; Hitzemann et al. 1993, 1994; Dains et al. 1996). Paradoxically, both somatodendritic and post-synaptic $\mathrm{D}_{2}$ receptor density are increased in the non-responsive animals (Hitzemann et al. 1991; Qian et al. 1992, 1993; Kanes et al. 1993, 1996; Cipp, 1995). Quantitative trait loci (QTL) analysis of the catalepsy response has revealed three QTLs which map near three likely candidate genes, Drd2, HTR2a, and Chat (Kanes et al. 1996; Rasmussen et al. 1997).

In the current study we have compared the Fos response to haloperidol in the C57BL/6J (B6) and DBA/2J (D2) inbred mouse strains. The $\mathrm{ED}_{50 \mathrm{~s}}$ for haloperidol-induced catalepsy in the D2 and B6 strains are 0.4 and $3.8 \mathrm{mg} / \mathrm{kg}$, respectively (Kanes et al. 1993). In contrast, these strains are equally sensitive to the haloperidol facilitation of prepulse inhibition (PPI) of the acoustic startle response (McCaughran et al. 1997), which is thought to reflect haloperidol's effects on the mesolimbic dopamine system (see e.g., Swerdlow et al. 1994), although, there also appears to be some involvement of the caudodorsal striato-pallidal circuitry (Kodsi and Swerdlow, 1995). Significant haloperidol effects on PPI are detected at 0.1 $\mathrm{mg} / \mathrm{kg}$. As a working hypothesis, we proposed that the Fos response to haloperidol in the D2 and B6 strains would parallel the results found for typical and atypical neuroleptics; in the dorsolateral $\mathrm{CPu}$, the $\mathrm{D} 2$ strain would be more sensitive to the effects of haloperidol, whereas in the nucleus accumbens (NAc) the strains would be equally sensitive. The alternative hypothesis was that the strains would be equally sensitive to the effects of haloperidol in the CPu and the NAc, but would differ significantly at the output nuclei of the basal ganglia i.e., the entopeduncular nucleus (EP) and the substantia nigra zona reticulata (SNr). Wirtshafter and Asin (1995) have demonstrated that haloperidol causes a dose dependent increase of Fos-li neurons in both the $\mathrm{EP}$ and $\mathrm{SNr}$ and concluded that these data are consistent with the idea that receptor blockade results in disinhibition of cells in these brain regions.

\section{METHODS}

\section{Animals}

Male C57BL/ 6 and DBA/2J mice weighing 18-24 g were obtained from Jackson Laboratories (Bar Harbor, ME). Animals were housed under 12-hour light-dark cycle, fed food and water ab libitum, and acclimated to the new environment for at least two weeks. For the three days prior to testing, the animals were injected once daily intraperitoneally (i.p.) with saline. On testing day, the animals were randomly assigned to one of six groups-saline or haloperidol $(0.1,0.3,1.0,3.0$, and $6.0 \mathrm{mg} / \mathrm{kg})$. Haloperidol (Sigma Chemical Co., St. Louis, MO) was dissolved in saline with minimal amount of acetic acid, further diluted before injection and administered i.p. Sixty minutes after drug or saline treatment, the animals were deeply anesthetized with a 7:5 mixture of xylazine $(8 \mathrm{mg} / \mathrm{kg}$; Miles Inc, KN) and ketamine $(60 \mathrm{mg} / \mathrm{kg}$; Fort Dodge Laboratories, Fort Dodge, IW). The animals were transcardially perfused with $0.9 \%$ saline solution, the brains were removed and fixed overnight in $4 \%$ paraformaldehyde in $0.1 \mathrm{M}$ phosphate buffer (PB), $\mathrm{pH}=7.4$.

\section{Immunohistochemistry}

The paraformaldehyde fixed brains were transferred to ice-cold 30\% sucrose in PB and were allowed to cryoprotect in this solution for $24-48$ hours. Thirty-micrometer frozen coronal sections were cut on a microtome and collected in $10 \mathrm{mM}$ phosphate buffered saline (PBS). The sections were rinsed three times in PBS and treated with $0.3 \% \mathrm{H}_{2} \mathrm{O}_{2}$ in PBS for fifteen minutes to block the endogenous peroxidase activity. The sections were rinsed in PBS six more times to remove the residual $\mathrm{H}_{2} \mathrm{O}_{2}$. The sections were then blocked for two hours in the immunoreaction buffer (10 mM PBS containing $0.25 \%$ Triton $\mathrm{X}-100$ and $3 \%$ goat serum) without antibody; antibody (final dilution 1:20,000) was than added and the incubation was continued for 60 to $72 \mathrm{hrs}$ at $4^{\circ} \mathrm{C}$. The antibody was obtained from Oncogene Science Inc. (Cambridge, MA); the antibody was raised against residues $4-17$ of human c-Fos protein.

The sections were rinsed three times in PBS and incu- 

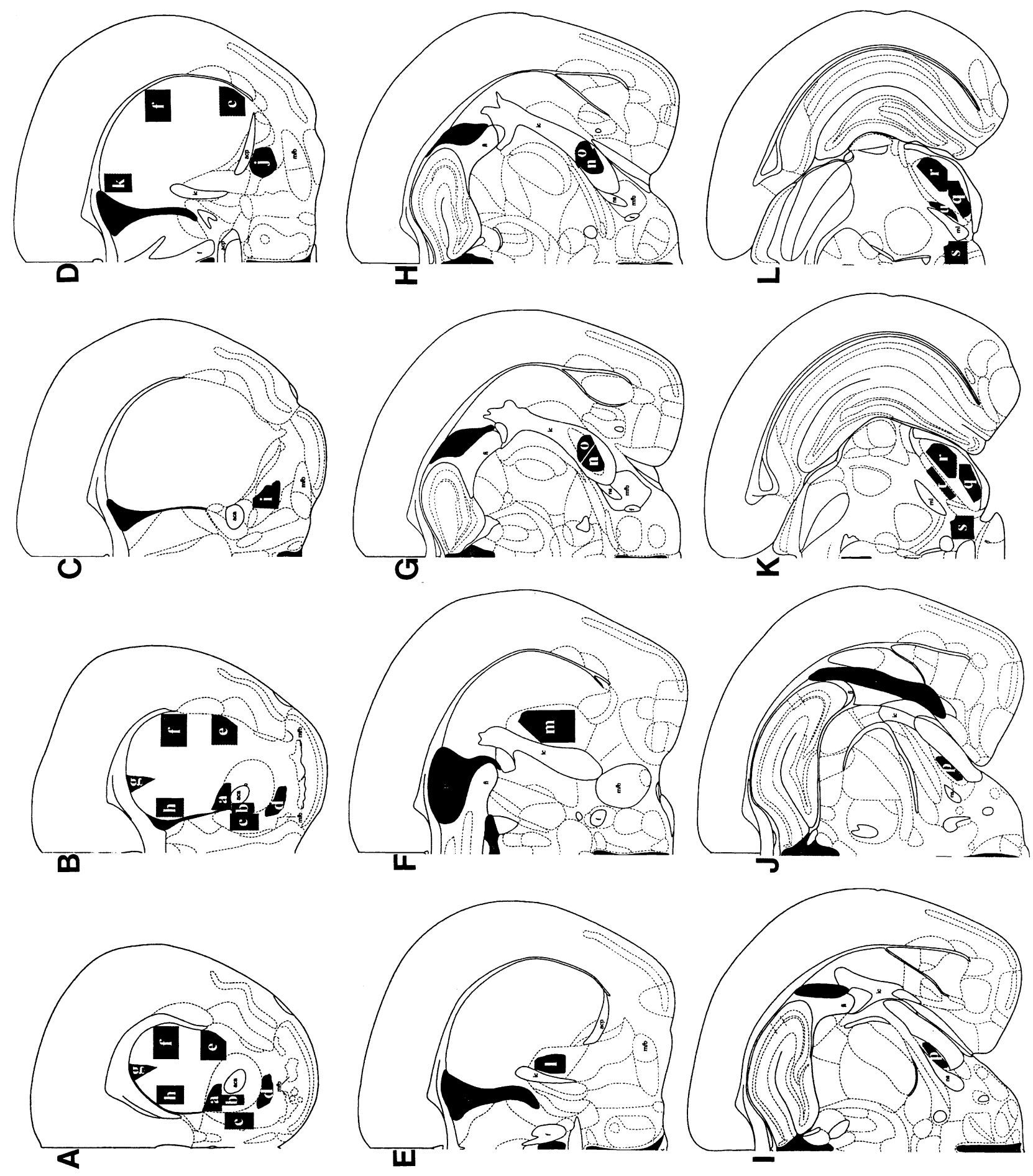


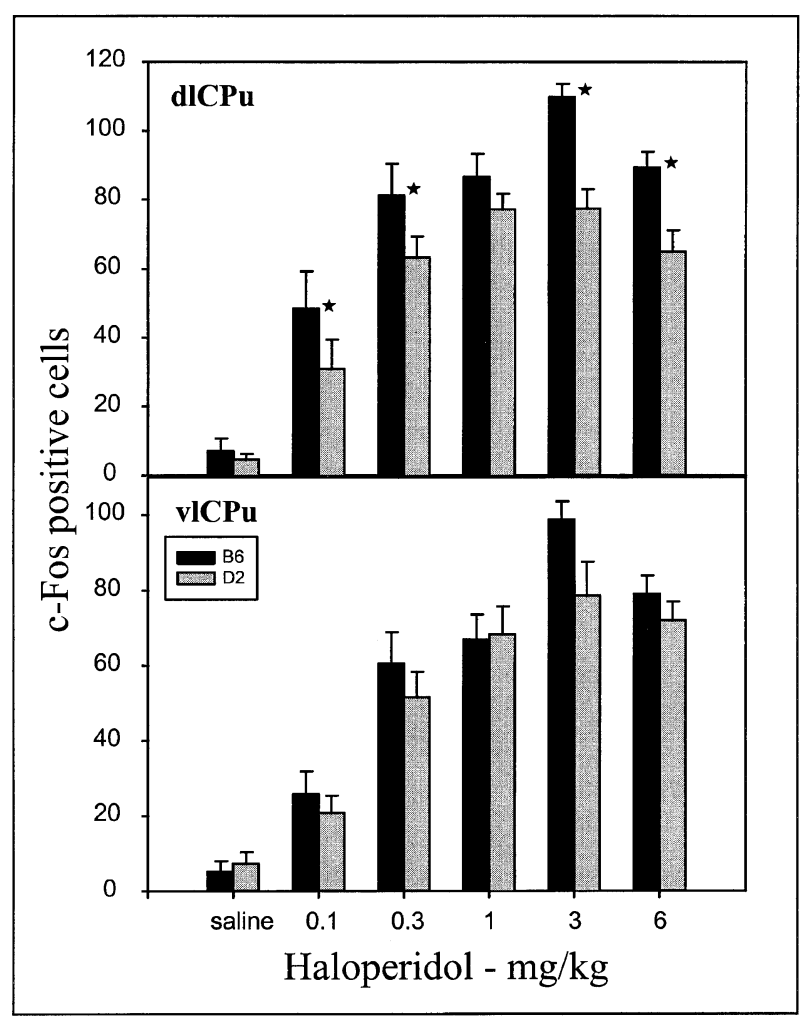

Figure 2. Effect of haloperidol on the number of Fos positive cells in the dorsolateral caudate-putamen $(\mathrm{v} 1 \mathrm{CPu})$ and the ventrolateral $\mathrm{CPu}(\mathrm{v} 1 \mathrm{CPu})$ : comparison of the C57BL/6J and DBA/2J Inbred Mouse Strains. Animals (males only) were administered various doses of haloperidol or vehicle 1 $\mathrm{hr}$ before sacrifice. The number of Fos positive neurons was detected by standard immunohistochemical techniques. $\mathrm{N}=$ 8-10 animals per treatment. Data are the mean \pm SE. * Significantly different from the DBA/2J strain; $p<10^{-2}$.

bated with the biotinylated goat anti-rabbit IgG (1:200 of secondary antibody) in $10 \mathrm{mM}$ PBS containing $0.3 \%$ Triton $\mathrm{X}-100$ and $3 \%$ goat serum for two hours at room temperature. The sections were subsequently incubated with horseradish peroxidase avidin-biotin complex in $10 \mathrm{mM}$ PBS for two hours at room temperature. The sections were rinsed three times in PBS and placed in $0.1 \mathrm{M}$ Tris ( $\mathrm{pH}$ 7.4) for 5 minutes. The chromatic reaction was accomplished with diaminobenzidine $(50 \mathrm{mg} /$ $100 \mathrm{ml}$ of $0.1 \mathrm{M}$ Tris) in presence of $0.01 \%$ nickel ammonium sulfate solution and $0.035 \%$ hydrogen peroxide. The sections were mounted onto slides, dehydrated and cover-slipped with Permount.

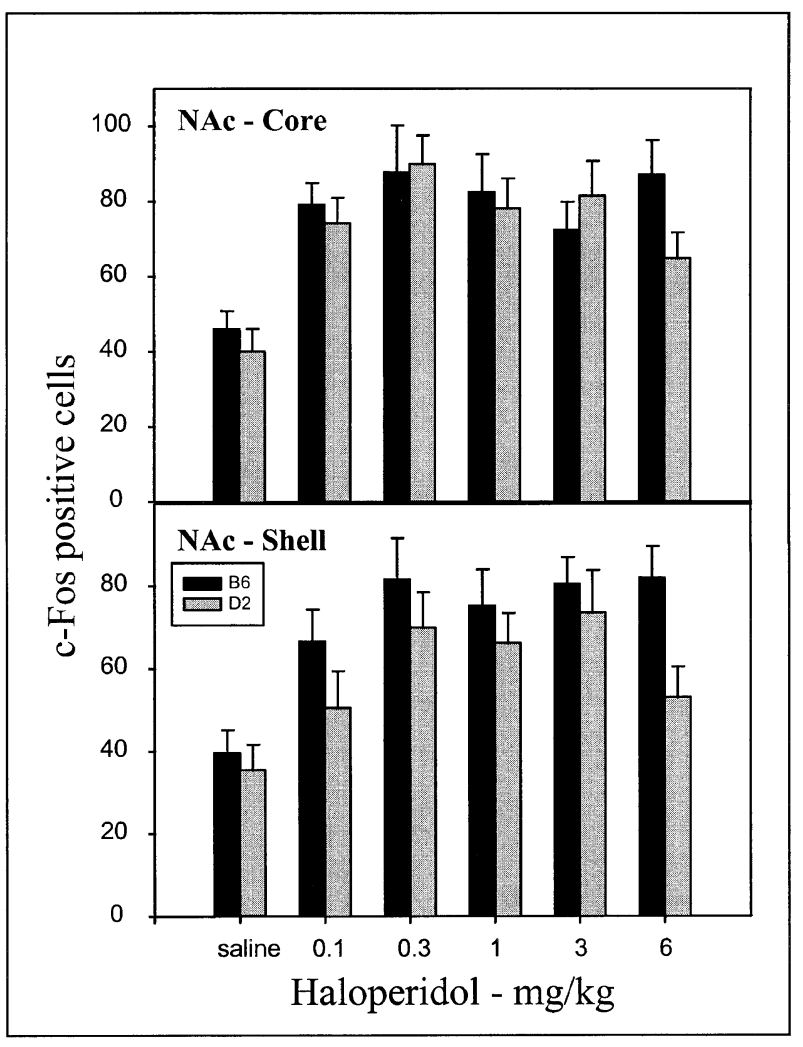

Figure 3. Effect of haloperidol on the number of Fos positive cells in the core and shell of the nucleus accumbens (NAc): comparison of the C57BL/6J and DBA/2J Inbred Mouse Strains. Details in the legend to Figure 2. For the core, data from the dorsal and medial aspects have been combined; for the shell, data from the medial and ventral aspects have been combined (see Figure 1).

\section{Image Analysis}

C-Fos positive nuclei were counted in seventeen regions of the basal ganglia (Figure 1) using MCID M1 imaging software (St. Catharines, Ontario, CA). The target region was captured using a black and white digitizing camera. The targets were enhanced (against the background) using a matrix function. Targets with perimeter and area greater than 8 pixels were selected within the templates shown in the Figure 1. The selected targets were manually examined for accuracy and incorrect selections were removed from the cell counts. Each region was counted at two rostral-caudal levels. The number of Fos-li neurons in a region were divided by the scan area to yield the number of Fos-li neurons within a $0.1 \mathrm{~mm}^{2}$ area.

Figure 1. Schematic illustration of the regions targeted for analysis a) dorsal core of the nucleus accumbens (NAc); b) medial core NAc; c) medial shell NAc; d) ventral shell - NAc; e) ventrolateral caudate-putamen $(\mathrm{CPu}) ; \mathrm{f})$ lateral $\mathrm{CPu}$; $\mathrm{g})$ dorsolateral $\mathrm{CPu}$; h) medial $\mathrm{CPu}$; i) ventral pallidum (VP) (rostral); j) VP (caudal); k) dorsomedial CPu; 1) globus pallidus (GP) (rostral); m) GP (caudal); n) medial entopeduncular nucleus (EP); o) lateral EP; p) subthalamic nucleus; q) medial substantia nigra zona reticulata (SNZr); r) lateral SNZr; s) ventral tegmental area (VTA); t) rostral SNZ compacta (SNZc); u) caudal SNZc. 


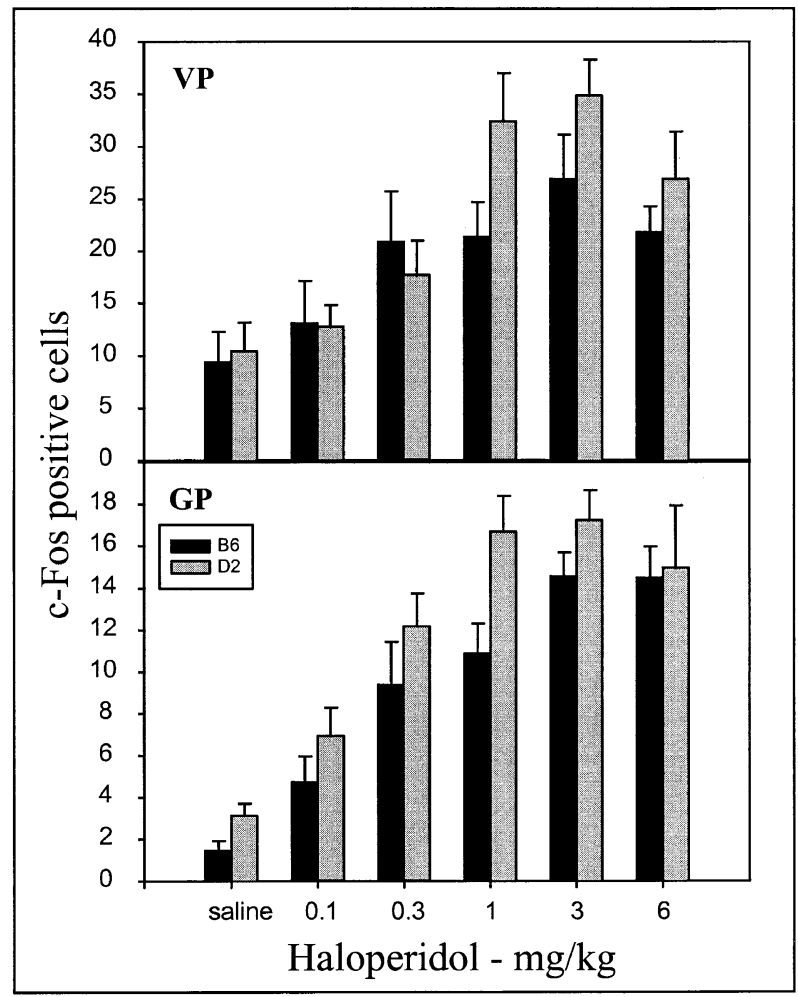

Figure 4. Effect of haloperidol on the number of Fos positive cells in the ventral pallidum (VP) and globus pallidus (GP): comparison of the C57BL/6J and DBA/2J Inbred Mouse Strains. Details in the legend to Figure 2.

\section{Statistical Methods}

The data were analyzed by standard analysis of variance techniques using Statistical software for Windows (Statsoft Inc., Tulsa, OK). Duncan's multiple range test was used for the post hoc analysis. Although multiple brain regions were examined, the Fos responses across regions and doses of haloperidol were highly correlated, thus reducing the number of independent tests. The number of such independent tests is clearly less than 102 (17 regions $\times 6$ treatment groups) but clearly more than 1 . As a compromise, we have set the minimum threshold for a significant effect at $p<10^{-2}$.

\section{RESULTS}

\section{Experimental Design}

Male D2 and B6 mice ( $\mathrm{N}=8-12$ /group) were injected once daily with saline for three consecutive days. On day 4 , the animals were administered either saline or haloperidol $(0.1,0.3,1,3$, or $6 \mathrm{mg} / \mathrm{kg})$. The $\mathrm{ED}_{50 \mathrm{~s}}$ for haloperidol-induced catalepsy in the D2 and B6 strains are 0.4 and $3.8 \mathrm{mg} / \mathrm{kg}$, respectively; at $6 \mathrm{mg} / \mathrm{kg}$, all of the animals were cataleptic using the method for assessment described previously (Hitzemann et al. 1991; Kanes et al. 1993). The animals were sacrificed one hour later and the number of Fos-like immunoreactive (Fosli) neurons in the basal ganglia was determined as de-

Table 1. Summary of the effects of haloperidol on the number of Fos-li neurons in the basal ganglia: comparison of the C57BL/6J (B6) and DBA/2J Inbred Mouse Strains ${ }^{\text {a }}$

\begin{tabular}{|c|c|c|c|c|c|c|c|c|c|c|c|c|}
\hline \multirow[b]{3}{*}{ Region/Strain } & \multicolumn{12}{|c|}{ Haloperidol } \\
\hline & \multicolumn{2}{|c|}{0} & \multicolumn{2}{|c|}{0.1} & \multicolumn{2}{|c|}{0.3} & \multicolumn{2}{|c|}{1.0} & \multicolumn{2}{|c|}{3.0} & \multicolumn{2}{|c|}{6.0} \\
\hline & B6 & D2 & B6 & D2 & B6 & D2 & B6 & D2 & B6 & D2 & B6 & D2 \\
\hline Dorsal Core-NAc ${ }^{b}$ & $47 \pm 5$ & $44 \pm 5$ & $77 \pm 5$ & $77 \pm 7$ & $79 \pm 12$ & $89 \pm 7$ & $73 \pm 9$ & $74 \pm 6$ & $61 \pm 6$ & $74 \pm 8$ & $84 \pm 9$ & $65 \pm 5$ \\
\hline Medial Core-NAc & $44 \pm 5$ & $36 \pm 6$ & $80 \pm 6$ & $71 \pm 6$ & $96 \pm 12$ & $90 \pm 7$ & $91 \pm 10$ & $82 \pm 8$ & $82 \pm 6$ & $88 \pm 10$ & $89 \pm 9$ & $64 \pm 7$ \\
\hline Medial Shell-NAc & $50 \pm 4$ & $45 \pm 6$ & $76 \pm 4$ & $64 \pm 6$ & $86 \pm 10$ & $87 \pm 5$ & $89 \pm 9$ & $78 \pm 7$ & $87 \pm 5$ & $94 \pm 10$ & $92 \pm 5$ & $65 \pm 5$ \\
\hline Ventral Shell-NAc & $29 \pm 5$ & $26 \pm 5$ & $56 \pm 8$ & $36 \pm 7$ & $76 \pm 9$ & $52 \pm 6$ & $61 \pm 6$ & $53 \pm 5$ & $73 \pm 6$ & $53 \pm 4$ & $71 \pm 7$ & $40 \pm 5$ \\
\hline Ventrolateral-CPu & $5 \pm 3$ & $7 \pm 3$ & $25 \pm 5$ & $20 \pm 4$ & $60 \pm 8$ & $51 \pm 6$ & $67 \pm 6$ & $68 \pm 7$ & $98 \pm 4$ & $78 \pm 8$ & $79 \pm 4$ & $72 \pm 4$ \\
\hline Dorsolateral-CPu & $7 \pm 4$ & $4 \pm 2$ & $48 \pm 10$ & $30 \pm 8$ & $81 \pm 9$ & $63 \pm 6$ & $86 \pm 6$ & $77 \pm 4$ & $109 \pm 3$ & $77 \pm 5$ & $89 \pm 4$ & $64 \pm 6$ \\
\hline Dorsal-CPu & $29 \pm 8$ & $22 \pm 5$ & $96 \pm 10$ & $74 \pm 5$ & $109 \pm 12$ & $86 \pm 7$ & $101 \pm 8$ & $79 \pm 4$ & $100 \pm 8$ & $99 \pm 7$ & $121 \pm 6$ & $75 \pm 6$ \\
\hline Medial-CPu & $45 \pm 7$ & $36 \pm 6$ & $85 \pm 7$ & $64 \pm 6$ & $91 \pm 12$ & $75 \pm 6$ & $72 \pm 9$ & $65 \pm 5$ & $73 \pm 9$ & $78 \pm 7$ & $90 \pm 6$ & $58 \pm 5$ \\
\hline VP & $9 \pm 3$ & $10 \pm 2$ & $13 \pm 4$ & $12 \pm 2$ & $20 \pm 4$ & $17 \pm 3$ & $21 \pm 3$ & $32 \pm 4$ & $26 \pm 4$ & $34 \pm 5$ & $21 \pm 2$ & $26 \pm 4$ \\
\hline GP & $2 \pm 1$ & $3 \pm 1$ & $4 \pm 1$ & $6 \pm 1$ & $9 \pm 2$ & $12 \pm 1$ & $10 \pm 1$ & $16 \pm 1$ & $14 \pm 1$ & $17 \pm 1$ & $14 \pm 1$ & $14 \pm 3$ \\
\hline Lateral-EP & $2 \pm 1$ & $4 \pm 1$ & $9 \pm 2$ & $10 \pm 2$ & $26 \pm 5$ & $34 \pm 3$ & $28 \pm 3$ & $37 \pm 5$ & $36 \pm 3$ & $39 \pm 3$ & $29 \pm 2$ & $28 \pm 5$ \\
\hline Medial-EP & $2 \pm 1$ & $10 \pm 2$ & $11 \pm 1$ & $34 \pm 6$ & $37 \pm 7$ & $68 \pm 5$ & $39 \pm 6$ & $74 \pm 4$ & $48 \pm 6$ & $81 \pm 4$ & $58 \pm 4$ & $69 \pm 6$ \\
\hline STh & $13 \pm 6$ & $10 \pm 2$ & $12 \pm 4$ & $15 \pm 2$ & $15 \pm 7$ & $16 \pm 5$ & $13 \pm 4$ & $8 \pm 2$ & $15 \pm 4$ & $27 \pm 10$ & $7 \pm 2$ & $11 \pm 2$ \\
\hline Medial-SNr & $1 \pm 1$ & $2 \pm 1$ & $3 \pm 1$ & $3 \pm 1$ & $9 \pm 5$ & $11 \pm 2$ & $10 \pm 2$ & $29 \pm 3$ & $20 \pm 2$ & $37 \pm 3$ & $29 \pm 4$ & $34 \pm 3$ \\
\hline Lateral-SNr & $1 \pm 1$ & $1 \pm 1$ & $1 \pm 1$ & $1 \pm 1$ & $3 \pm 2$ & $2 \pm 1$ & $3 \pm 1$ & $6 \pm 1$ & $5 \pm 0$ & $7 \pm 1$ & $4 \pm 1$ & $4 \pm 1$ \\
\hline $\mathrm{SNc}$ & $28 \pm 4$ & $9 \pm 2$ & $31 \pm 6$ & $28 \pm 6$ & $34 \pm 7$ & $48 \pm 5$ & $47 \pm 6$ & $40 \pm 5$ & $49 \pm 4$ & $45 \pm 6$ & $58 \pm 6$ & $34 \pm 3$ \\
\hline VTA & $9 \pm 2$ & $6 \pm 1$ & $10 \pm 1$ & $19 \pm 3$ & $26 \pm 4$ & $34 \pm 3$ & $28 \pm 4$ & $34 \pm 4$ & $32 \pm 2$ & $42 \pm 5$ & $28 \pm 4$ & $27 \pm 2$ \\
\hline
\end{tabular}

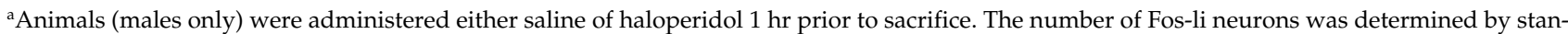
dard immunohistological techniques. Data are the mean \pm SE from 8-12 animals per treatment.

${ }^{b}$ Abbreviations: nucleus accumbens (NAc); caudate-putamen (CPu); globus pallidus (GP); ventral pallidum (VP); subthalamic nucleus (STh); entopeduncular nucleus (EP); substantia nigra zona reticulata (SNr); substantia nigra zona compacta (SNc); ventral tegmental area (VTA). 


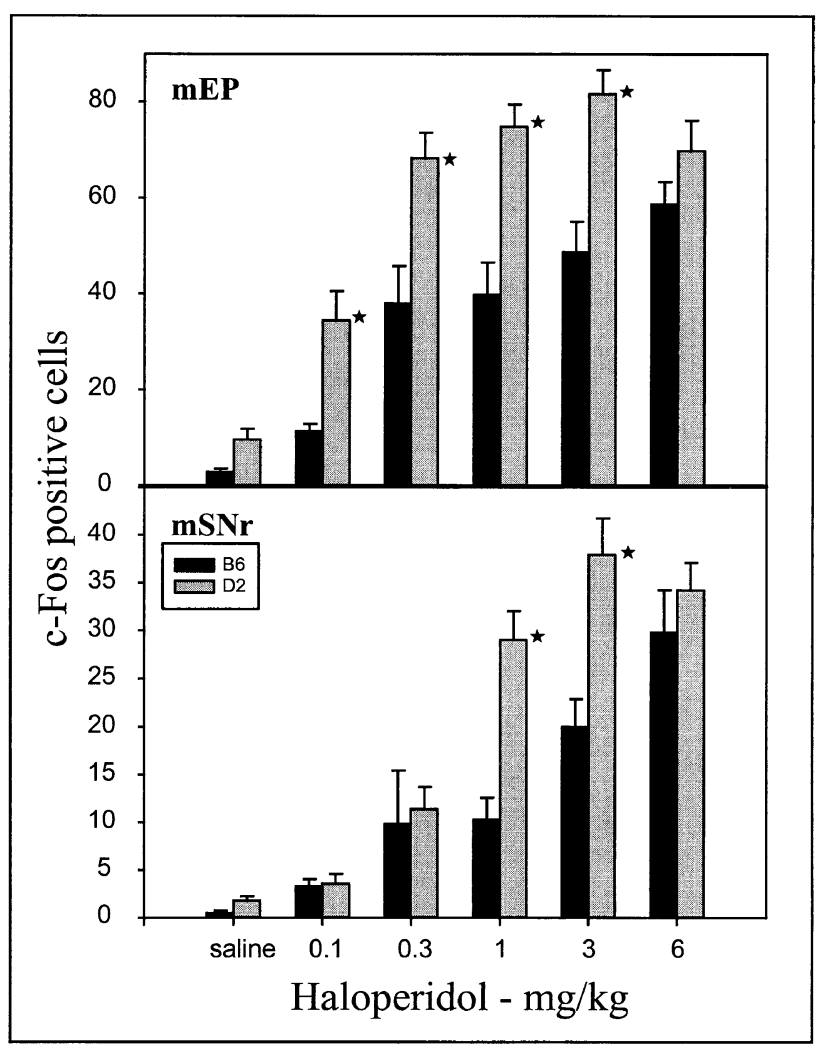

Figure 5. Effect of haloperidol on the number of Fos positive cells in the medial entopeduncular nucleus (mEP) and the medial substantia nigra zona reticulata ( $\mathrm{mSNr}$ ): comparison of the C57BL/6J and DBA/2J Inbred Mouse Strains. Details in the legend to Figure 2. *Significantly different from the C57BL/6J strain; $p<10^{-2}$.

scribed in Methods. The one hour time course was chosen on the basis of pilot data which showed that the maximal Fos response is obtained 60-90 minutes after haloperidol administration; by three hours the response has significantly decreased. This observation of a rapid Fos response is consistent with the time-course found by others using various paradigms to stimulate Fos expression (e.g., Franza et al. 1987, 1988; Sonnenberg et al. 1989; Dilts et al. 1993). No significant differences were observed along the rostral-caudal axis within a given region (see Figure 1), thus all data and statistical analysis presented here are based on the average of data taken from two rostral-caudal levels. Each region was analyzed independently. A tabular summary of the results are presented in Table 1.

\section{Caudate-Putamen}

Four regions of the caudate-putamen $(\mathrm{CPu})$ were examined: medial, dorsomedial, dorsolateral, and ventral lateral (Figure 1). For the dorsolateral $\mathrm{CPu}$, the ANOVA revealed significant effects for treatment $\left(F_{5,297}=290\right.$, $\left.p<10^{-5}\right)$, strain $F_{1,297}=88, p<10^{-5}$ ) and the treatment $\times$

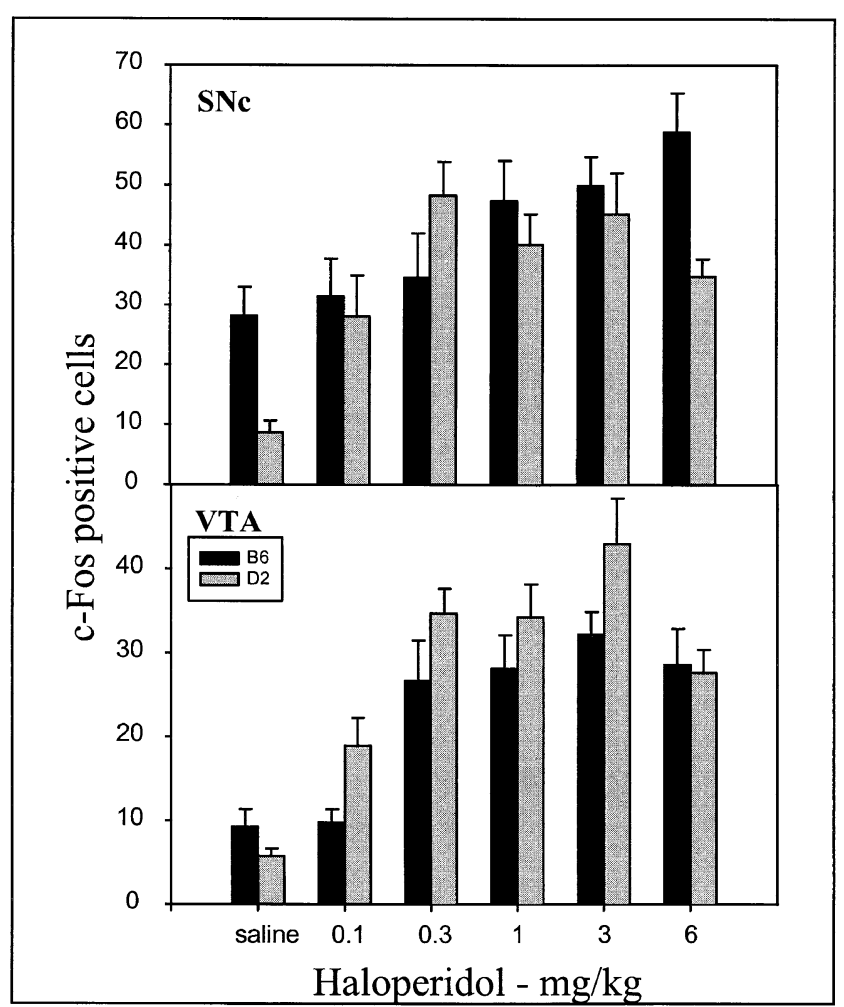

Figure 6. Effect of haloperidol on the number of Fos positive cells in the substantia nigra zona compacta (SNc) and the ventral tegmental area (VTA): comparison of the C57BL/ $6 \mathrm{~J}$ and DBA/2J Inbred Mouse Strains. Details in the legend to Figure 2.

strain interaction $\left(F_{5,297}=7.1, p<10^{-4}\right)$. Post hoc analysis of the strain $\times$ treatment interaction revealed that the B6 strain showed a modest but significantly greater increase of Fos-li neurons in the $\mathrm{CPu}$ at all doses of haloperidol except $1 \mathrm{mg} / \mathrm{kg}$ (Figure 2). Representative images from this region are presented in Figure 7a. For the ventrolateral $\mathrm{CPu}$ and dorsal $\mathrm{CPu}$, the ANOVA revealed significant strain $\times$ treatment interactions $\left(F^{\mathrm{vlCPu}}{ }_{5,297}=3.5, p<4 \times 10^{-2} ; F^{\mathrm{dCPu}_{5,297}}=3.2, p<8 \times\right.$ $10^{-2}$ ). For the ventrolateral $\mathrm{CPu}$, the $\mathrm{B} 6$ strain showed a significantly greater increase in the number of Fos-li neurons at $3 \mathrm{mg} / \mathrm{kg}$ haloperidol (Figure 2). In the medial $\mathrm{CPu}$, there was no significant strain $\times$ treatment interaction $\left(F_{5,198}=2.1, p<6 \times 10^{-2}\right)$.

\section{Nucleus Accumbens}

The core of the nucleus accumbens (NAc) was divided into dorsal and medial aspects (Figure 1). Significant effects were detected for treatment $\left(F_{5,198}=15, p<10^{-5}\right)$ and region $\left(F_{1,198}=9.7, p<10^{-3}\right)$ but not for strain, the treatment $\times$ region, strain $\times$ region or the treatment $\times$ strain $\times$ region interactions. The treatment $\times$ strain interaction $\left(F_{5,197}=1.7, p<1.2 \times 10^{-1}\right)$ did not meet the 

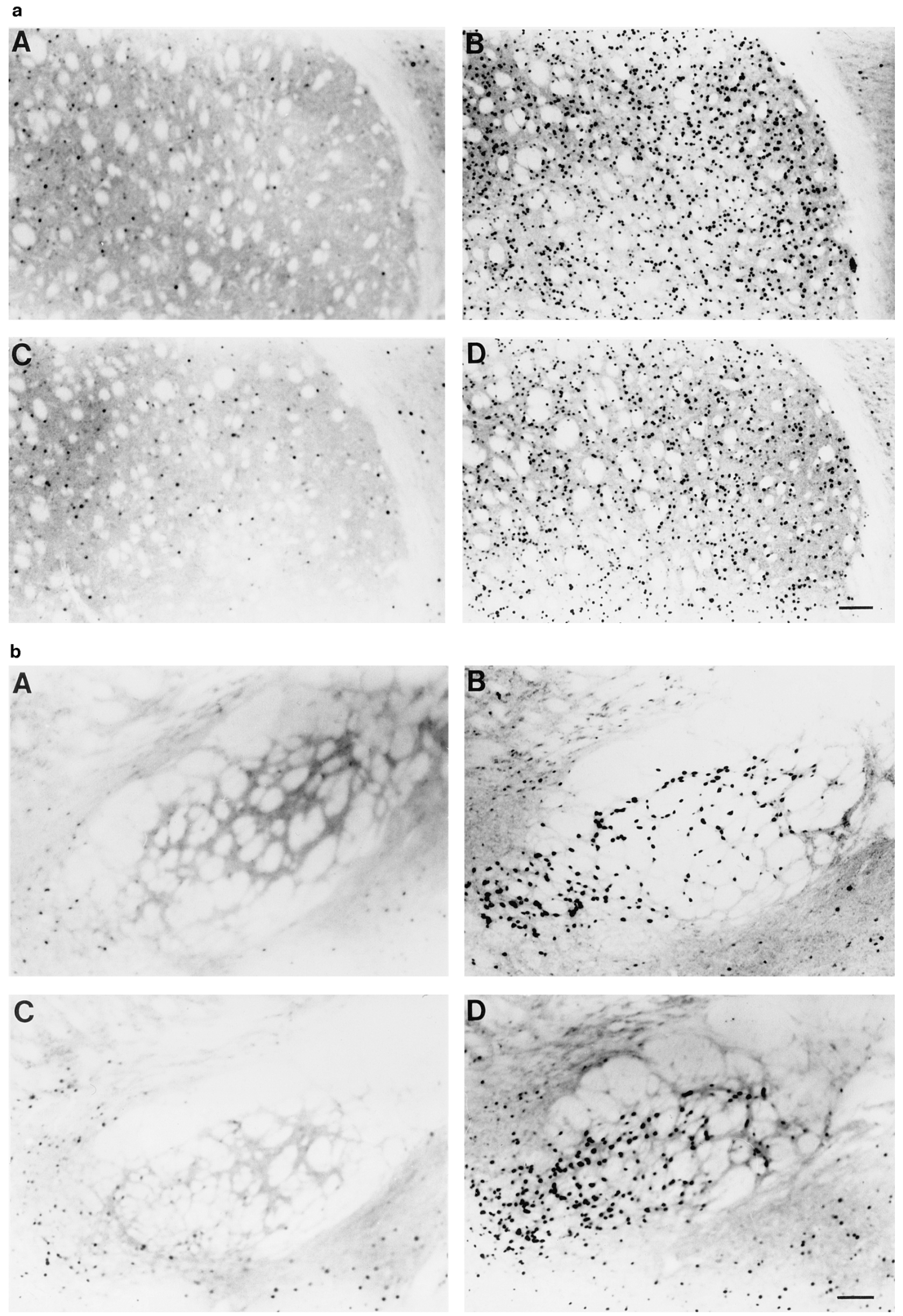
C
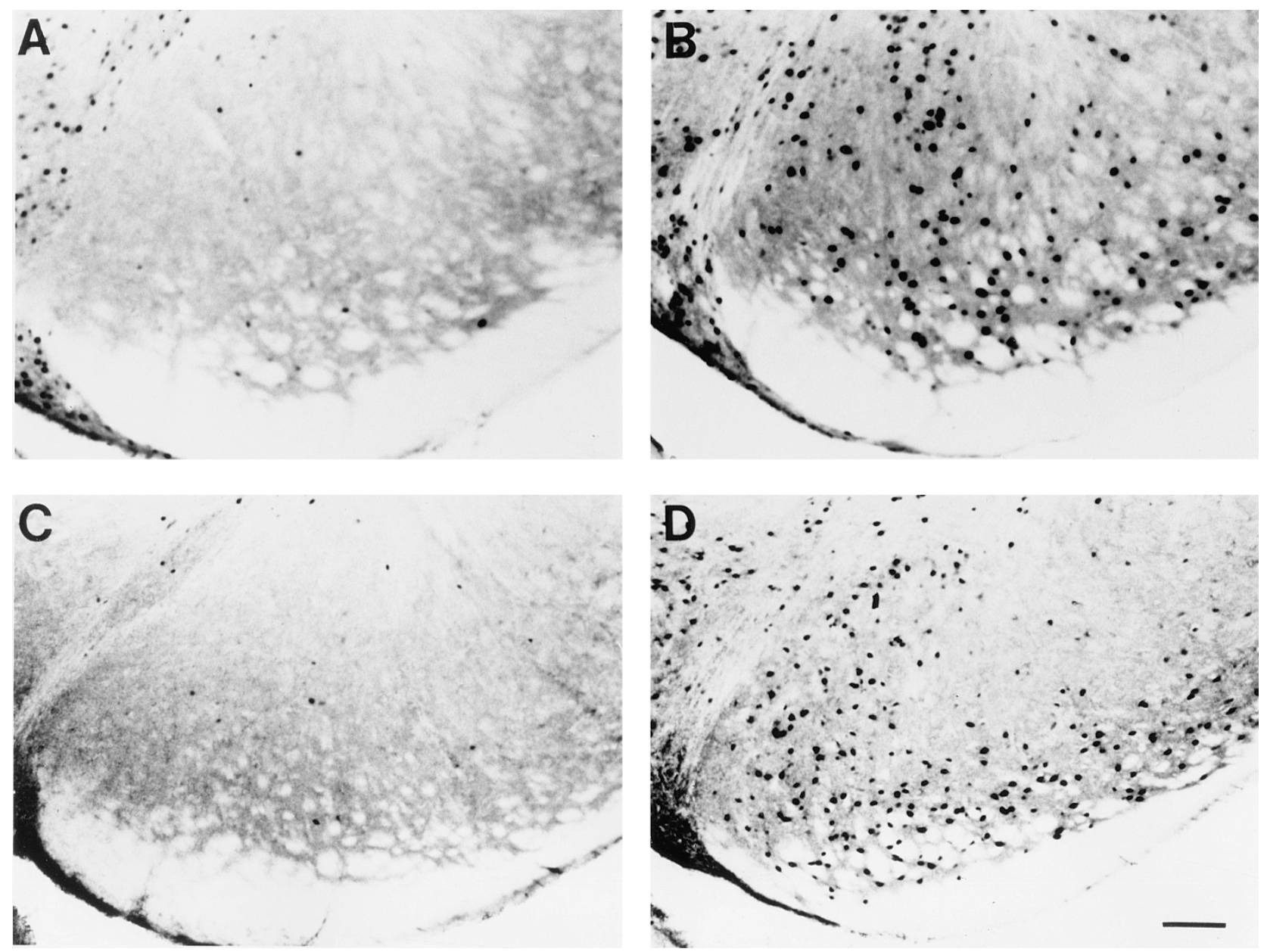

Figure 7a. Representative photomicrographs showing the Fos response to saline and $1 \mathrm{mg} / \mathrm{kg}$ haloperidol in the dorsolateral CPu: comparison of the C57BL/6J and DBA/2J Inbred Mouse Strains. A) saline C57BL/6J; B) $1 \mathrm{mg} / \mathrm{kg}$ haloperidol C57BL/6J; C) saline DBA/2J; D) $1 \mathrm{mg} / \mathrm{kg}$ haloperidol DBA $/ 2 \mathrm{~J}$. Bar $=100 \mu \mathrm{m}$.

Figure 7b. Representative photomicrographs showing the Fos response to saline and $1 \mathrm{mg} / \mathrm{kg}$ haloperidol in the EP: comparison of the C57BL/6J and DBA/2J Inbred Mouse Strains. Details in Figure 7a.

Figure 7c. Representative photomicrographs showing the Fos response to saline and $1 \mathrm{mg} / \mathrm{kg}$ haloperidol in the SNr: comparison of the C57BL/6J and DBA/2J Inbred Mouse Strains. Details in Figure 7a.

$10^{-2}$ threshold for significance; these data are presented in Figure 3. As in the $\mathrm{CPu}, 0.1 \mathrm{mg} / \mathrm{kg}$ haloperidol induced marked increases ( $>75 \%$ ) in the number of Fosli neurons in both strains.

The shell of the NAc was divided into a medial and ventral component (Figure 1). Significant effects were detected only for treatment $\left(F_{5,197}=23, p<10^{-5}\right)$. The treatment $\times$ strain interaction $\left(F_{5,197}=1.9, p<10^{-1}\right)$ did not meet the threshold for significance; these data are presented in Figure 3. As in the core, the haloperidol effect was marked, approximately doubling the number of Fos-li neurons in both strains over the dose range of 0.3 to $3 \mathrm{mg} / \mathrm{kg}$.

\section{Ventral Pallidum, Globus Pallidus, and Subthalamic Nucleus}

For the ventral pallidum (VP) significant effects were detected only for treatment $\left(F_{5,198}=26, p<10^{-5}\right)$. The treatment $\times$ strain interaction $\left(F_{5,198}=2.6, p<3 \times 10^{-2}\right)$ did not meet the $10^{-2}$ threshold for significance. These data do however, suggest a trend to a greater effect in the D2 strain at the 1 and $3 \mathrm{mg} / \mathrm{kg}$ haloperidol doses (Figure 4).

For the globus pallidus (GP) significant effects were detected for treatment $\left(F_{5,198}=82, p<10^{-5}\right)$ and strain $\left(F_{1,198}=22, p<10^{-4}\right)$ but not for the treatment $\times$ strain interaction $\left(F_{5,198}=2.1 p<6 \times 10^{-2}\right)$; these data are pre- 
sented in Figure 4. On average, the number of Fos-li neurons in the D2 strain was 31\% higher as compared to the B6 strain across all treatments. No significant effects were detected in the subthalamic nucleus (STh); these data are summarized in Table 1.

\section{Entopeduncular Nucleus, Substantia Nigra Zona Reticulata and Compacta, and Ventral Tegmental Area}

The entopeduncular nucleus (EP) was divided into a lateral and medial component (Figure 1); given the marked difference in the number of Fos-li neurons, the two components were analyzed separately. In the lateral EP, there was a significant effect for treatment $\left(F_{5,194}=88\right.$, $p<10^{-5}$ ) but not for the treatment $\times$ strain interaction $\left(F_{5,194}=1.4, p<2 \times 10^{-1}\right)$. For the medial EP significant effects were detected for treatment $\left(F_{5,194}=120, p<\right.$ $\left.10^{-5}\right)$, strain $\left(F_{1,194}=132, p<10^{-5}\right)$ and the treatment $\times$ strain interaction $\left(F_{5,197}=7.4, p<10^{-4}\right)$. These latter data are presented in Figure 5 and illustrate that over the dose range of 0.1 to $3 \mathrm{mg} / \mathrm{kg}$ haloperidol, the number of Fos-li neurons was significantly higher in the D2 strain. Representative images from this region are found in Figure $7 \mathrm{~b}$.

The substantia nigra zona reticulata $(\mathrm{SNr})$ was divided into a lateral an medial component (Figure 1). As shown in Table 1, the lateral aspect contained few Fos-li neurons and these data were not analyzed further. For the medial $\mathrm{SNr}$, significant effects were detected for treatment $\left(F_{5,194}=91, p<10^{-5}\right)$, strain $\left(F_{1,194}=42, p<\right.$ $\left.10^{-5}\right)$ and the treatment $\times$ strain interaction $\left(F_{5,194}=11\right.$, $\left.p<10^{-5}\right)$. As shown in Figure 5, the D2 strain showed a significantly greater response in ventral SNZr at 1 and 3 $\mathrm{mg} / \mathrm{kg}$. Representative images are shown in Figure 7c.

For the substantia nigra zona compacta (SNc) significant effects were detected only for treatment $\left(F_{5,194}=\right.$ $\left.19, p<10^{-5}\right)$. The treatment $\times$ strain interaction $\left(F_{5,194}=\right.$ 2.3, $p<5 \times 10^{-2}$ ) was not significant. However, the data suggest a great number of Fos-li neurons in the B6 strain as compared to the D2 strain at $6 \mathrm{mg} / \mathrm{kg}$ haloperidol (Figure 6).

For the ventral tegmental area (VTA) significant effects were detected for treatment $\left(F_{5,194}=47, p<10^{-5}\right)$ and strain $\left(F_{1,194}=10, p<10^{-3}\right)$. The treatment $\times$ strain interaction $\left(F_{5,194}=2.8, p<2 \times 10^{-2}\right)$ did not meet the $10^{-2}$ threshold for significance. However, the data suggest that over the dose range of 0.1 to $3 \mathrm{mg} / \mathrm{kg}$ haloperidol, the number of Fos-li neurons was higher in the D2 strain (Figure 6).

\section{DISCUSSION}

Previous studies from this laboratory have established that the D2 and B6 inbred mouse strains differ almost 10-fold in their sensitivity to haloperidol-induced catalepsy, a putative animal model of EPS (Kanes et al. 1993). In contrast, we have recently observed that the D2 and B6 strains are equally sensitive to the haloperidol facilitation of prepulse inhibition (PPI) of the acoustic startle response (McCaughran et al. 1997); presumably, this increase in PPI results largely from haloperidol's effects on the mesolimbic dopamine system (see e.g., Swerdlow et al. 1994). Further, the D2 and B6 strains are equally sensitive to the increase in PPI seen after the administration of the atypical neuroleptics, clozapine, and risperidone. These data led us to postulate that the D2 and B6 strains would differ in their Fos response to haloperidol in the same way that rats and nonhuman primates differ in their response to haloperidol and clozapine (e.g. Dragunow et al. 1990; Nguyen et al. 1992; Deutch and Cameron 1992; Deutch et al. 1996; Robertson et al. 1994). Thus, it was expected that compared to the B6 strain, the D2 strain would show a greater increase in the number of Fos-li neurons in the dorsolateral $\mathrm{CPu}$ after haloperidol treatment, but the strains would be equally sensitive to the effects of haloperidol in the NAc. The data in Figures 2 and 7a, b, and c clearly establish that the D2 strain does not show a greater Fos response in the dorsolateral $\mathrm{CPu}$; in fact the data suggest that the $\mathrm{B} 6$ strain which has a higher density of $\mathrm{D}_{2}$ dopamine receptors in the $\mathrm{CPu}$ (Kanes et al. 1993; Erwin et al. 1993) is moderately but significantly more sensitive to the effects of haloperidol. Interestingly, in the NAc there were no difference in the Fos response, even though $D_{2}$ receptor density is significantly higher in the B6 strain (Kanes et al. 1993; Erwin et al. 1993). Overall, these data illustrate that the striatal Fos response to haloperidol in the B6 and D2 inbred strains does not predict the behavioral outcome (catalepsy). In preliminary studies of the BALB/cJ and LP/J strains, we have found similar results; these strains are the extreme phenotypes and differ more than 30-fold in their haloperidol $\mathrm{ED}_{50 \mathrm{~s}}$.

The alternative working hypothesis was that the D2 and B6 strains would differ at the output nuclei of the basal ganglia. The data in Figure 5 support this hypothesis. The D2 strain showed a greater Fos response in both the EP and SNr. The effect in the EP was detected over a wide range of haloperidol doses $(0.1$ to $3 \mathrm{mg} / \mathrm{kg})$ and in the $\mathrm{SNr}$ at 1 and $3 \mathrm{mg} / \mathrm{kg}$ of haloperidol. If the Fos positive neurons in the EP and $\mathrm{SNr}$ are the GABA efferents which project to the thalamus, these data may explain the differential behavioral response. These data support and extend the observations of Wirtshafter and Asin (1995) who noted that in the rat, both haloperidol $(0.5-8 \mathrm{mg} / \mathrm{kg})$ and metoclopramide $(6.25-50 \mathrm{mg} / \mathrm{kg})$ cause a dose dependent increase in the number of Fos-li neurons in the rostral portion of the EP and the medial aspect of the SNr. The regions sampled in the present study were similar to those used by Wirtshafter and 
Asin (1995) and we confirm that it is the medial and not the lateral aspect of the $\mathrm{SNr}$ which responds to drug treatment; furthermore, we confirm that the Fos responsive neurons in the $\mathrm{SNr}$ are not immunoreactive for tyrosine hydroxylase (unpublished observation). These authors also performed a number of important control experiments which are pertinent to the current results. They observed that the Fos response is blocked by pretreatment with scopolamine and was not mimicked by the administration of $5-\mathrm{HT}_{2 \mathrm{~A} / \mathrm{C}}$ and $5-\mathrm{HT}_{3}$ antagonists. This latter point is of important since at high doses haloperidol has significant $5-\mathrm{HT}_{2 \mathrm{~A} / \mathrm{C}}$ antagonist activity.

The question arises as to what are the likely mechanism(s) which could explain the differential response of the B6 and D2 strains in the EP and SNr. In this regard, the "intermediate" nuclei of the $\mathrm{D}_{2}$ receptor "indirect" pathway (the GP and the STh) (Gerfen et al. 1990) were not informative. Given the low number of Fos-li neurons in the GP of the saline group, it was not possible to detect a haloperidol-induced decrease in this region (the expected response). In fact a modest Fos response was observed in the GP; Ruskin and Marshall (1996) have suggested that these responsive neurons actually project back to the striatum. Given the circuitry of the striatopallidal pathway, it was predicted that haloperidol should induce a substantial Fos response in the STh; however, in both strains, the STh was essentially unresponsive to haloperidol treatment. Thus, we must conclude that at least in the mouse, Fos expression does not tract the expected responses to haloperidol treatment in the GP and STh.

The possibility must be considered that the differential Fos response in the EP and $\mathrm{SNr}$ is mediated by differences in the activity of the "direct" $\mathrm{D}_{1}$ pathway (Gerfen et al. 1990). In this regard, one must consider whether or not at the doses used, haloperidol will occupy a significant proportion of the $\mathrm{D}_{1}$ receptors. The dose of $0.3 \mathrm{mg} / \mathrm{kg}$ which showed the maximum between strain difference in the EP Fos response, should produce a brain haloperidol level of approximately 3 nM (adapted from Kanes et al. 1993). The affinity of haloperidol in either strain brain for $\mathrm{D}_{2}$ and $\mathrm{D}_{1}$ receptors, respectively is 1 and $100 \mathrm{nM}$ (unpublished observations; see also Seeman and Van Tol 1994. Thus at 0.3 $\mathrm{mg} / \mathrm{kg}, \mathrm{D}_{2}$ and $\mathrm{D}_{1}$ receptor occupancies will be $75 \%$ and $2.9 \%$, respectively. However, at $6 \mathrm{mg} / \mathrm{kg}, \mathrm{D}_{1}$ receptor occupancy will be substantial $(39 \%)$ and one cannot discount the possibility of $D_{1}$ receptor mediated effects on the Fos response. In this regard, Wirtshafter and Asin (1995) found that the administration of the $D_{1}$ antagonist, SCH 23390 (2-8 mg $/ \mathrm{kg})$, produced a relatively weak Fos response in the EP and SNr.

From the behavioral perspective there are at least two reasons to believe that the $\mathrm{D}_{1}$ system is not important to the differential haloperidol response: 1) There are no significant differences among inbred strains of mice (including the D2 and B6 strains) in SCH 23390 induced catalepsy-a corollary to this observation is the lack of substantial differences in $\mathrm{D}_{1}$ receptor density among strains (Kanes et al. 1993: Erwin et al. 1993); and 2) Drugs such as raclopride which have essentially no activity at $\mathrm{D}_{1}$ sites, also differentiate haloperidol responsive and non-responsive animals (Hitzemann et al. 1991).

We recognize the liabilities associated with extracting causal relationships from a two strain comparison. The D2 and B6 strains are highly polymorphic and may differ in the catalepsy response for reasons that would not be reflected by differences in the Fos-response within the basal ganglia. From a statistical perspective, a two strain comparison is equivalent to a two-point regression analysis. We view the data presented here as a first step. The results clearly demonstrate that it is not necessary for there to a difference in the Fos-response within the dorsolateral $\mathrm{CPu}$ in order for there to be marked difference in sensitivity to haloperidol-induced catalepsy. Further, the data suggest some "downstream" targets which may be potential sites of the genetic variance. To test such hypotheses, we are currently crossing the $\mathrm{B} 6$ and $\mathrm{D} 2$ strains to form an $\mathrm{F}_{2}$ population from which the phenotypic extremes for catalepsy will be tested for the Fos-response. Alternatively, one could examine the Fos-response in the extreme strains (see Kanes et al. 1996) of the BXD recombinant inbred series. In both strategies, the heritability for catalepsy is high $(>0.75)$ (Kanes et al. 1996; Dains et al. 1996).

\section{ACKNOWLEDGMENTS}

This study was supported in part by grants from the National Institute of Mental Health (MH-51372), from the Department of Veterans Affairs, and from the National Alliance for Research on Schizophrenia and Depression.

\section{REFERENCES}

Carelli RM, West MO (1991): Representation of the body by single neurons in the dorsolateral straitum of the awake, unrestrained rat. J Comp Neurol 309:231-249

Cipp L (1995): Genetics, dopamine and behavior. M.S. Thesis. Stony Brook, NY, Dept. of Molecular and Cellular Pharmacology, SUNY Stony Brook

Dains K, Hitzemann B, Hitzemann R (1996): Genetics, neuroleptic-response and the organization of cholinergic neurons in the mouse striatum. J Pharmacol Exp Therap 279:1430-1438

Deutch AY, Cameron DS (1992): Pharmacological characterization of dopamine systems in the nucleus accumbens core and shell. Neuroscience 46:49-56

Deutch AY, Lewis DA, Whitehead RE, Elsworth JD, Iadarola MJ, Redmond DE, Roth RH (1996): Effects of D2 dopa- 
mine receptor antagonists on Fos protein expression in the striatal complex and entorhinal cortex of the nonhuman primate. Synapse 23:182-191

Dilts RP, Helton TE, McGinty JE (1993): Selective induction of Fos and FRA immunoreactivity within the mesolimbic and mesostriatal dopamine terminal fields. Synapse $13: 251-263$

Dragunow M, Robertson GS, Faull LM, Robertson HA, Jansen K (1990): D2 dopamine receptor antagonists induce fos and related proteins in rat striatal neurons. Neuroscience 37:287-294

Erwin VG, Womer DE, Campbell AD, Jones BC (1993): Pharmacogenetics of cocaine: II. Mesocorticolimbic and striatal dopamine receptors in C57BL and DBA mice. Pharmacogenetics 3(4) 189-196

Franza BR, Sambucetti LC, Cohen DR, Curran T (1987): Analysis of fos protein complexes and fos-related antigens by high resolution two-dimensional gel electrophoresis. Oncogene 1:213-221

Franza BR, Rauscher FJ, Josephs SF, Curran T (1988): The fos complex and fos-related antigens recognize sequence elements that contain AP-1 binding sites. Science 239:1150-1153

Gerfen CR, Engber TM, Maha LC, Susel Z, Chase TN, Monsma FJ, Sibley DR (1990): D1 and D2 dopamine receptor-regulated gene expression of striatonigral and striatopallidal neurons. Science 250:1429-1432

Guo N, Robertson GS, Fibiger HC (1992): Scopolamine attenuates haloperidol-induced c-fos expression in the striatum. Brain Res 588:164-167

Heimer L, Zahm DS, Alheid GF (1995): Basal Ganglia. In Paxinos G (ed), The Rat Nervous System, 2nd ed. San Diego, Academic Press, pp 579-628

Hitzemann RJ, Dains K, Bier-Langing CM, Zahniser NR (1991): On the selection of mice for haloperidol response and non-response. Psychopharmacology 103:244-250

Hitzemann R, Qian Y, Hitzemann B (1993): Dopamine and acetylcholine cell density in the neuroleptic responsive (NR/Ibg) and neuroleptic non-responsive (NNR/Ibg) lines of mice. J Pharmacol Exp Ther 266:431-438

Hitzemann B, Dains K, Kanes S, Hitzemann R (1994): Further studies on the relationship between dopamine cell density and haloperidol-induced catalepsy. J Pharmacol Exp Ther 271:969-976

Hitzemann R, Qian Y, Kanes S, Dains K, Hitzemann B (1995): Genetics and the organization of the basal ganglia. Int Rev Neurobiol 38:43-94

Ishibashi T, Ikeda K, Ishida K, Yasui J, Tojima R, Nakamura M, Ohno Y (1996): Contrasting effects of SM-9018, a potential atypical antipsychotic, and haloperidol on c-fos mRNA expression in the rat striatum. Eur J Pharmacol 303:247251

Kanes S, Hitzemann B, Hitzemann R (1993): On the relationship between $D_{2}$ receptor density and neurolepticinduced catalepsy among eight inbred strains of mice. J Pharmacol Exp Ther 267:538-547

Kanes S, Dains K, Cipp L, Gatley J, Hitzemann B, Rasmussen E, Sanderson S, Silverman M, Hitzemann R (1996): Mapping the genes for haloperidol-induced catalepsy. J Pharmacol Exp Therap 277:1016-1025
Kinon BJ, Kane JM (1989): Difference in catalepsy response in inbred rats during chronic haloperidol treatment is not predictive of the intensity of behaviorally hypersensitivity which subsequently develops. Psychopharmacology 98:465-471

Kodsi MH, Swerdlow NR (1995): Prepulse inhibition in the rat is regulated by ventral and caudodorsal striato-pallidal circuitry. Behavioral Neurosci 109:912-928

McCaughran J Jr, Mahjubi E, Decena E, Hitzemann R (1997): Genetics, haloperidol-induced catalepsy and haloperidol-induced changes in acoustic startle and prepulse inhibition. Psychopharmacology 134:131-139

Merchant KM, Dorsa DM (1993): Differential induction of neurotensin and c-fos gene expression by typical versus atypical antipsychotics. Proc Natl Acad Sci USA 90: 3447-3451

Miller JC (1990): Induction of c-fos mRNA expression in rat striatum by neuroleptic drugs. J Neurochem 54:1453-1455

Nguyen TV, Kasofsky B, Birnbaum R, Cohen BM, Hyman SE (1992): Differential expression of Fos and Zif 268 in rat striatum following haloperidol, clozapine and amphetamine. Proc Natl Acad Sci USA 89:4270-4274

Pisa M (1988): Motor functions of the striatum in the rat: critical role of the lateral region in tongue and forelimb reaching. Neuroscience 24:453-463

Qian Y, Hitzemann B, Hitzemann R (1992): $D_{1}$ and $D_{2}$ dopamine receptor distribution in the neuroleptic nonresponsive (NNR) and neuroleptic responsive (NR) lines of mice -a quantitative receptor autoradiographic study. J Pharmacol Exp Ther 261:341-348

Qian Y, Hitzemann B, Yount G, White J, Hitzemann R (1993): $D_{1}$ and $D_{2}$ dopamine receptor turnover and $D_{2}$ mRNA levels in the neuroleptic-responsive (NR) and neuroleptic non-responsive (NNR) lines of mice. J Pharmacol Exp Ther 267:1582-1590

Rasmussen E, Cipp L, Hitzemann R (1997): Haloperidolinduced catalepsy maps to the piebald (s) but not the albino $(c)$ locus in a CXLP cross. Behav Gen, in press

Robertson GS, Fibiger HC (1992): Neuroleptics increase c-Fos expression in the forebrain: contrasting effects of haloperidol and clozapine. Neuroscience 46:315-328

Robertson GS, Matsumura H, Fibiger HC (1994): Induction patterns of Fos-like immunoreactivity in the forebrain as predictors of atypical antipsychotic activity. J Pharmacol Exp Therap 271:1058-1066

Robertson GS, Fibiger HC (1996): Effects of olanzapine on regional c-Fos expression in rat forebrain. Neuropsychopharmacology 14:105-110

Ruskin DN, Marshall JF (1995): D1 receptors influence Fos immunoreactivity in the globus pallidus and subthalamic nucleus of intact and nigrostriatal-lesioned rats. Brain Research 703:156-164

Ruskin DN, Marshall JF (1996): The dopaminergic induction Fos immunoreactivity in identified populations of globus pallidus neurons. Soc Neuroscience Abstract \#797.5, Washington, DC

Seeman P, Van Tol HHM (1994): Dopamine receptor pharmacology. TIPS 15:264-270

Sonnenberg JL, Mitchelmore C, MacGregor-Leon PF, Hemp- 
stead J, Morgan JI, Curran T (1989) Glutamate receptor agonists increase the expression of Fos, Fra and AP-1 DNA binding activity in mammalian brain. J Neurosci Res 24:72-80

Swerdlow NR, Braff DL, Taaid N, Geyer MA (1994): Assessing the validity of an animal model of deficient sen- sorimotor gating in schizophrenic patients. Arch Gen Psych 51:139-154

Wirtshafter D, Asin KE (1995): Dopamine antagonists induce fos like immunoreactivity in the substantia nigra and entopeduncular nucleus. Brain Res 670:205-214 